\title{
The method of withdrawal of unused agricultural land plots from the owners
}

\author{
Elena Aleksandrovna Pozdnyakova ${ }^{1}$ \\ Higher School of Economics, Department of Theory of Law and Interdisciplinary Legal Disciplines, \\ Faculty of Law, Moscow, Russia
}

\begin{abstract}
The purpose of the study is to identify the problems of withdrawal of unused agricultural land plots from the owners and to determine the ways to solve them. The methodological basis of the research is the analysis of regulatory legal documents, statistical data, scientific publications, as well as deduction and synthesis. The application of these methods made it possible to characterize the mechanism of withdrawal of unused agricultural land plots from the owners and to identify problems in this area; to propose measures for elimination of the identified problems. The study resulted in the following provisions: there is no consensus in the scientific community on the advisability of withdrawing unused agricultural land plots, since countries that effectively use agricultural land are developing in terms of quality, thereby emphasizing the absence of the need to increase the area; the solution of food security problem by involving unused agricultural land plots in circulation is currently acceptable for Russia, since the country currently have no mechanism for replacement of the number of areas with production intensification. The novelty of the research lies in identification of the problem of unused land trading in the absence of those wishing to purchase it. Moreover, the author's approach to solving the issue of economy efficiency improvement includes the involvement of such land plots in circulation by expanding the methods used, in particular, the tools of economic and imperative methods.
\end{abstract}

Keywords: efficiency, intended use, performance of duties, public authorities

\section{Introduction}

According to the Land Code of the Russian Federation adopted on October 25, 2001 (Article 7), all lands are divided into categories, the most valuable of which is the category of agricultural land. Agricultural land requires constant cultivation, rational and careful use, as the most valuable land. Only in this case, the fertility of the land can be preserved and the problem of food security can be ultimately solved. However, the same is not true. A number of owners have appeared who do not want or cannot use such lands for their intended purpose or use them in violation of the law, but in either case, the lands lose their fertility,

${ }^{1}$ Corresponding author: epozdnyakova@hse.ru 
which takes decades to restore, and in some cases is impossible. Having realized the severity of the emerging problem, the state had to act in order to find a solution to it. The decision to return such lands to civilian circulation through the procedure of their withdrawal from the owners was the top priority.

The implementation of this decision was carried out using the imperative method over the past five years. However, despite all the efforts, the desired result was achieved only in a small part, which clearly did not eliminate the indicated problem. This fact served as the basis for studying the reasons for the low efficiency of solving this issue. The results obtained will make it possible to determine the ways to improve efficiency and determine the methods for solving the identified problem.

\section{Methods}

The methodological basis of the research is the analysis of regulatory legal documents, statistical data, scientific publications, as well as deduction and synthesis. The application of these methods made it possible to characterize the mechanism of withdrawal of unused agricultural land plots from the owners and to identify problems in this field; to propose measures for elimination of the identified problems.

\section{Results and discussion}

The idea of a withdrawal of the unused agricultural land plots provided for the solution of food security due to the greater number of use of such plots for their intended purpose. However, the increase in quantity not in every instance guarantees the desired result. This is exactly what E.A. Minina emphasized, saying that agriculture in the modern world is developing through intensification, rather than through the development of new areas, and the built-up territories constantly require expansion [1, p. 228]. Despite the fact that the effect caused by revisions in the use of land plots by the owners and other land users is felt in Russia, the legislator considered that the withdrawal procedure is exactly the mechanism that is needed to provide the country with food, having begun to form the legal framework for this issue.

Consequently, in 2016, Federal Law No. 354-FZ "On amendments to certain legislative acts of the Russian Federation in terms of improving the procedure for withdrawal of the land plots from agricultural lands when they are not used for their intended purpose or used in violation of the RF law" appeared [2]. In the course of implementation of this law at the government level, it was noted that it was an extreme measure, but it was necessary to resort to it [3].

However, in scientific circles, not everyone agreed with this statement. The norms laid down in it were criticized at the stage of a draft law [4]. They are being criticized even nowadays. In particular, there is a point of view in the literature that, in general, the withdrawal of lands that are used in violation of the law is a powerful land-legal instrument able, among other things, to play a significant role in ensuring the rational use and protection of lands. However, the real effectiveness of these norms is significantly lower than possible [1, p. 221].

Moreover, there is no unambiguous approach to evaluation of the very nature of the withdrawal procedure. For example, according to one point of view, such an exemption should be considered as a type of responsibility for violation of the law, defining it as a special land-legal responsibility [5, pp. 86-90; 6, pp. 93-96; 7, pp. 16-20]. According to another point of view, the withdrawal of land in the event of its improper use is not so much 
a punitive measure as a way to ensure the most rational use of land in the interests of the whole society through the redistribution of land resources [1, p. 220]. The authors share the third point of view that the purpose of withdrawal of a land plot from an offender should be to transfer it to another, more responsible owner [8, p. 47]. In this regard, the authors believe that it is necessary to analyze the methodology for the implementation of the procedure for the withdrawal of such land plots, since the wrong methods chosen can lead to negative results.

The imperative method used by the authorities in the withdrawal of agricultural land in the event of their non-use or use in violation of the law is central to this study. Along with it, the method of analysis, the comparative legal method, the method of economic incentives etc. were also used.

First, it was necessary to identify such land plots. Such information is usually provided by the bodies exercising land supervision (control). In accordance with clause 2 of the "Regulations on State Land Supervision" [9], state land supervision is carried out by the Federal Service for State Registration of Cadastre and Cartography (Rosreestr), the Federal Service for Veterinary and Phytosanitary Supervision and the Federal Service for Supervision of Natural Resource Use and their territorial bodies.

The legal status of the Federal Service for State Registration of Cadastre and Cartography (Rosreestr) is established in accordance with applicable regulatory legal acts, as well as administrative regulations and orders of the Rosreestr itself.

In 2020, Rosreestr moved from the jurisdiction of the Ministry of Economic Development of Russia to the direct subordination of the Government of the Russian Federation as part of the change in the structure of executive authorities. As a result of this change, the powers of Rosreestr were significantly expanded [10, pp. 332-339].

The above-mentioned function of land supervision (control) is implemented by Rosreestr through an imperative method. In particular, during inspections Rosreestr records the fact of non-use of such a land plot. This fact is an important element in the supervision procedure, since withdrawal is possible if the land plot has not been used for its intended purpose for three years or if the use leads to a decrease in the fertility of agricultural land or causes harm to the environment. This is followed by the application of an administrative penalty with an order to eliminate the identified violations.

In the event that the identified violations have not been eliminated, the state land supervision body sends the materials to the executive body of the constituent entity of the Russian Federation, which subsequently, within two months, applies to the court with a demand to withdraw such a land plot from agricultural land and sell it at a public auction. All these actions are performed by the state using the method of power and subordination, no alternative is provided in this case, the procedure is described by the legislator in some detail.

If the public auction took place, then the land plot acquires a new owner. The situation is much more complicated with land plots that were not purchased either at the first auction or at the second, and the sale through a public offer also did not bring the desired result. In this case, the land plot must be acquired into the municipal ownership of the settlement or urban district, the territory on which it is located. If this acquisition did not take place, then such a land plot must be acquired by the executive authority of the constituent entity of the Russian Federation within one month.

The problem lies in the fact that such land plots may be unattractive to both the municipal authorities and the authorities of the constituent entity of the Russian Federation. Moreover, very often there is no money for their purchase in the corresponding budget. In this case, the executive authorities of the constituent entity of the Russian Federation are not 
interested in legal action on the issue of the withdrawal of such a land plot and its subsequent sale at a public auction. In this case, it can be assumed that the use of the imperative method prevents the achievement of the goal - namely, the transfer of an unused agricultural land plot to a person willing to use it for its intended purpose.

It is believed by the authors, that the way out of this situation is to use the method of economic incentives along with the imperative method. The justification for the need for its application can be found in the works of Russian scientists [11]. Besides, the successful application of this methodology can be seen in world practice. In particular, the withdrawal of unused or irrationally used land plots from the owners with payment of compensation is contained in the French Civil Code [12]. Special organizations SAFER have been created in the country, the purpose of which is to develop the land use and agricultural enterprises. They also monitor and identify the most efficient farmers, to whom most of the agricultural land is subsequently sold. At the same time, there is a tendency towards a decrease in the ownership of agricultural land plots, in favor of the lease of such plots. According to Eurostat [13], in 2017 France ranked first in the production of agricultural products in Europe with an indicator of 73 billion euros, ahead of Germany (56 billion euros), Italy (55 billion euros), Spain (51 billion euros) and others.

This mechanism is also stipulated in the legislation of Germany, where agricultural land is used most effectively, including the Constitution of Germany [14], the Civil Code of Germany [15], the Building Code [16], the Federal Law on Spatial Planning. Simultaneously with the withdrawal of such lands, the issues of leasing such lands have been settled and a system of special courts has been created. The procedure for concluding lease agreements for land plots is carried out in accordance with the German Civil Code as amended by the Law on the New Procedure for Agricultural Lease dated February 08, 1985 [17].

In 1981 in the United States, an Act on Agricultural Lands Protection Policy was adopted, which substantiates the need for taking measures at the federal level to preserve farmland and prevent its unjustified transfer for other purposes [18]. For this purpose, budget funds are allocated to help farmers to implement anti-erosion measures and material incentives for participation in soil conservation programs. This is not accidental, since the function that incites the development of economic ties and the effective use of property is of particular importance in the United States [19, pp. 10-13], which is combined with the definition of property rights, which is understood as legally attached to a person expectations of the opportunity to extract one or other benefit from certain property [20, $\mathrm{p}$. 68].

Thus, when solving the problem of food security and agricultural land management the practice of other countries includes not only imperative method, but other ones, moreover, the economic method is central to them.

\section{Conclusion}

Summing up the above, the authors believe that before drawing a conclusion about the methodology for the withdrawal of unused agricultural land plots, the absence of consensus on the advisability of such withdrawal should be kept in mind, since the countries that effectively use agricultural land, are developing in terms of quality and have no need to increase the area. The authors assume that the solution of food security by involving unused agricultural land plots in circulation is currently acceptable for Russia, since there is no mechanism for replacement of the number of areas with production intensification. 
The use of such a mechanism provides for the use of an imperative method, from the stage of identification of such land plots to their sale at auction. In the study, we have identified the problem of sale such a land plot in the absence of those wishing to purchase it. However, this is not the only problem. This method does not solve the issue and the involvement of unused agricultural land plots in the turnover, which gives no possibility to evaluate this method as effective in solving the problem under consideration.

In our opinion, the solution to the issue of increasing efficiency through the involvement of such land plots in circulation should be the expansion of the methods used, in particular the tools of the economic method. This is justified not only by the positive experience of developed countries, but also by the provisions of Russian legislation. First, land cultivation is just a kind of entrepreneurial activity that is carried out freely at one's own peril and risk. Secondly, any entrepreneurship based on the imperative method will not be effective without economic incentives, since this limits its freedom. Thirdly, agriculture needs support from the state, without which it cannot be effective. Moreover, this support should not only be financial in the form of various tax benefits, subsidies and concessional lending, but it should also be targeted.

At the same time, we believe that the imperative method should be exercised as a form of supervision (control) over the targeted use of agricultural land.

\section{References}

1. E.A. Minina, Legal support for the rational use of land, in E.A. Galinovskaya (ed.), Legal Mechanism for Ensuring the Rational Use of Natural Resources, 207-235 (Infra-M, Moscow, 2019)

2. Federal Law No. 354-FZ "On amendments to certain legislative acts of the Russian Federation in terms of improving the procedure for withdrawal of the land plots from agricultural lands when they are not used for their intended purpose or used in violation of the RF law" dated 03.07.2016, in Collected Legislation of the Russian Federation, 27, 4287 (2016)

3. How does the Law on Acquisition of Agricultural Land Work. Accessed on: February 27, 2021. [Online]. Available:

https://1k-k.ru/zemli-vozvrashhayutsya-kak-rabotaet-zakon-ob-izyatii-selxozzemel/

4. V.Ya. Uzun, What does the Ministry of Agriculture want: to improve the use of land or to increase payments to its controllers and invaders? Accessed on: February 26, 2021. [Online]. Available:

https://www.dairynews.ru/news/chego-khochet-minselkhoz-uluchshit-ispolzovanie-ze. html

5. A.P. Anisimov, S.A. Charkin, Eurasian Legal Journal, 51, 86-90 (2012)

6. E.S. Boltanova, Journal of Russian Law, 12, 93-96 (2014)

7. E.A. Sukhova, Lawyer, 2, 16-20 (2014)

8. E.A. Galinovskaya, Journal of Russian Law, 1, 41-48 (2014)

9. Resolution of the Government of the Russian Federation of 02.01.2015. No. 1 "On Approval of the Regulation on State Land Supervision", published on the "Official Internet Portal of Legal Information" (www.pravo.gov.ru) on January 4, 2015.

10. L.P. Podbolotova, Changes in the powers of Rosreestr in 2020, taking into account the Resolution of the Government of the Russian Federation of 07.09.2020. №1369, in D.A. Shapovalova, S.I. Komarova (eds.), Digitalization of land use and cadastres: 
trends and prospects, Materials of the international scientific-practical conference, 332-339 (GUZ, Moscow, 2020)

11. Hlystun V.N., Murasheva A.A. Organizational and economic mechanisms for involving of agricultural lands into circulation, use and protection, 568 (Moscow, 2020)

12. France. Lois et ordonnances Code civil des Français (Code Napoléon). Accessed on: February28, 2021. [Online]. Available: https://pravo.hse.ru/intprilaw/doc/041401

13. Eurostat - Comptes de l'agriculture (2017 provisoire)

14. Das Grundgesetz (GG) ist die Verfassung für die Bundesrepublik Deutschland, Accessed on: February 28, 2021. [Online]. Available:

https://www.bundestag.de/grundgesetz

15. Burgerliches Gesetzbuch Deutschlands mit Einfuhrungsgesetz (1900). Accessed on: February28, 2021. [Online]. Available:

http://oceanlaw.ru/wp-content/uploads/2018/02/1900-Гражданское-уложение-1.pdf

16. Baugesetzbuch (BauGB). Accessed on: February28, 2021. [Online]. Available: https://www.drjv.org/dgesetze.html

17. Gesetz zur Neuordnung des Iandwirtschaftlichen Pachtrechts, BGBI.TI, 55, 2065 (1985)

18. Federal Land Policy and Management Act (1976). Accessed on: February 28, 2021. [Online]. Available: https://www.blm.gov/sites/blm.gov/files/AboutUs_LawsandRegs_FLPMA.pdf

19. R.A. Posner, Economic Analysis of Law, 10-13 (Little, Brown and Co, Boston, 1972)

20. J. Bentham, Theory of Legislation, (Oceana Publications, New York, 1975) 